\title{
Barriers to the Adoption of Waste-Reducing Eco-Innovations in the Packaged Food Sector: A Study in the UK and the Netherlands
}

Chris Simms, Paul Trott, Erik Jan Hultink \& Ellis van Den Hende

\begin{abstract}
The food processing sector has a considerable environmental impact, due to large volumes of food and packaging waste. Eco-innovations present an important opportunity to reduce this impact. Yet, initial insights suggest that new technologies face considerable challenges to their adoption. The eco-innovation adoption literature has overlooked the food processing sector. The purpose of this paper is to examine the barriers inhibiting the adoption of waste reducing eco-innovations in the food processing sector. We present four detailed case studies of new technologies at different stages of adoption in the UK and Netherlands. The findings reveal ten barriers to the adoption of waste reducing technologies in the food processing sector. The barriers identified include concerns over the influence of technologies on the product's characteristics, its retailing, and a perceived lack of consumer demand. These barriers arise from the powerful influence of retailers within the food supply chain, the influence of technologies on in-store point of sale displays, and the need for distribution trials. We conclude that the adoption of new technologies requires simultaneous acceptance by both food processor and retailers. The paper provides recommendations for policy makers and innovation managers to increase the adoption and diffusion of waste reducing technologies in the food processing sector, as well as implications for future research.
\end{abstract}

\section{Keywords:}

- Eco-innovation adoption

- Food waste

- Packaging waste

- Food supply chain

- Technological adoption

\section{Highlights:}

- Interconnected barriers are identified across key members of the food supply chain

- Specific characteristics of waste reducing eco-technologies impede their adoption

- Retailers role in the adoption of waste reducing technologies is uncovered

- Policy action is required to promote adoption at each level of the supply chain 


\section{Introduction}

The purpose of this paper is to examine the barriers to the adoption of new technological eco-innovations that specifically aim to reduce food and packaging waste. Across the developed world increases in food production and consumption have resulted in increased amounts of food and packaging waste (see Bailey, 1999; Parfitt et al., 2010; Hanssen et al., 2012). This development has resulted in growing attention and legislation from governments, policy makers, and the media. Within Europe the key policies to tackle waste include the Community European Policy and EU Waste Management Policy (Da Cruz et al., 2014; Johnson and Corcelle, 1997). Each policy places the primary emphasis on waste reduction, followed by recovery and disposal. The food industry is responsible for around $20-30 \%$ of the environmental impacts of consumption across the EU (Trott and Simms, 2017; Tukker and Jansen, 2006). Food products are consumed on a daily basis and often have a short shelf life. This results in significant food and packaging waste (Section 2.1; Table 1). The importance of reducing food and packaging waste is increasingly recognised (see Quested and Johnson, 2009; Williams and Wikstrom, 2011; Table 1).

Technological innovation represents a critical opportunity to respond to sustainability challenges, including those presented for both food and packaging waste reduction (European Commission, 2014; Morand and Barzman, 2006). For example, efficient new product-packaging technologies can reduce food waste and minimise material impact (see Poyatos-Racionero et al., 2018; Mariesse et al., 2013; Marsh and Bugusu, 2007). The majority of technological innovations come from outside the food industry (Trott and Simms, 2017). Yet, initial insights suggest that new technologies may face significant challenges to their acceptance (see RECAPT Report, 2014; Peinemann et al., 2011; Simms and Trott, 2014 a,b; Trott and Simms, 2017).

Our study is positioned within the literature on the barriers to eco-innovation adoption, and in particular within the agri-food sector supply chain (e.g. Guerin, 2001; Luken and Rompaey, 2007; Montalvo, 2008; Brunke et al., 2014; Luthra et al., 2014; Long et al., 2015; Bossle et al., 2016). Prior studies have either focused at the agricultural level of the supply chain (Long et al., 2015) or consist of surveys analysing the adoption of several types of ecoinnovation practices by food firms (Bossle et al., 2016). This results in a lack of a detailed understanding of the barriers to waste-reducing eco-innovation adoption within food processors and contract packaging firms ${ }^{1}$. Our paper addresses the following question: How

\footnotetext{
${ }^{1}$ Contract packaging firms package products on behalf of their clients. In the context of this research these clients may be food processors or growers.
} 
do barriers within the food supply chain influence packaged food firms' adoption of waste reducing eco-innovations?

Our research is conducted in the packaged food sector, which reached a value of $£ 62$ billion in the UK and a total of $\$ 571$ billion in Western Europe in 2018, with households consuming almost four times more packaged foods than fresh products (Euromonitor, 2018a,b). The empirical data for this paper uses four case studies. We study the adoption of four technologies from separate product categories with waste reducing benefits, examining each key supply chain level. Our findings contribute to the existing eco-innovation adoption literature. Firstly, we develop a framework that reveals barriers unique to the food processing sector. This framework identifies the high degree of interrelatedness between these barriers at each supply chain level. Secondly, we uncover that adoption is dependent on simultaneous adoption decision-making within both food processors and retailers.

The remainder of this article proceeds as follows. First, our literature review identifies the importance of waste reduction in the food industry, and then proceeds to review the literature on eco-innovation and technology adoption in the food sector. Secondly, we discuss our methodology. Finally, we present our findings, cross-case analysis, conclusions, and implications for both innovation management and sustainability academics and practitioners.

\section{Literature Review}

\subsection{Environmental Impact of the Food Industry: Food and Packaging Waste}

The proportion of resource usage and environmental impact attributable to the food industry across Europe has been calculated at around 20-30\% (Tukker and Jansen, 2006; see Table 1). The nature of the products it produces contributes heavily to this impact. Food products are characterised by a high frequency of purchase, consumption and disposal, combined with perishability (Bovea et al., 2006), resulting in high levels of waste. Considering the significant resources consumed in food production, measures to reduce waste hold the potential for significant reductions in impact (Williams et al., 2008). Further, firms also face increasing pressures to reduce packaging waste. Yet, in many categories of the food sector the impact of packaging is relatively small compared to its potential to reduce food waste (see Williams and Wilkstrom, 2011).

INSERT TABLE 1 ABOUT HERE 
Concerns over waste has resulted in the development of a number of governmental, negotiated and industry based initiatives across Europe (Bailey, 1999). The majority of these follow the Waste Hierarchy Principle (Da Cruz, et al., 2014), which prioritizes waste prevention and reduction, followed by reuse, recycling, energy recovery, and disposal. This creates a need to consider recyclability, biodegradability, weight, reducing resource usage, material content and smarter packaging (e.g. Mariesse, et al., 2013). These findings inform the rationale for our study examining eco-innovation adoption, with an emphasis on food processors adoption of technologies that reduce food and packaging waste, and resource usage. This is in contrast to prior studies that have characterised either: barriers to consumer behavior changes leading to food waste reduction, or barriers to the reduction of packaging within the industry itself (e.g. van Sluisveld and Worrel, 2013; Graham-Rowe et al., 2014; Visschers et al., 2016).

\subsection{The Adoption of Eco-Innovation Technologies}

Eco-innovations consist of product, process, marketing, systems and organisational innovations (Horbach et al., 2012; Leach et al., 2012). The areas in which environmental burdens can be reduced include: material usage per unit, energy usage per unit, emissions, pollution (water, soil or noise), replacing hazardous substances, and increased recycled inputs or increased recyclability of outputs (Horbach et al., 2012).

The diffusion of environmental innovations is critical (Kemp and Pontoglio, 2011). Yet, scholars have reported on the reluctance of firms to develop and implement ecotechnologies (Hart and Dowell, 2011; Guerin, 2001). This has led to a growing number of studies that examine their adoption, and the precluding barriers they face (Guerin, 2001; Luken and Rompaey, 2007; Montalvo, 2008; Brunke et al., 2014; Luthra et al., 2014). Our study argues that the nature of the food sector presents a number of unique challenges to eco-innovation adoption.

Technological adoption plays a critical role in food and packaging waste improvements. The majority of innovations originate from outside the food industry (Trott and Simms, 2017; Avermaete et al., 2004). Yet, studies examining the adoption of technological ecoinnovations are lacking. Initial insights suggest that new technologies, which frequently incorporate processing, product and packaging innovations, face significant obstacles (see Simms and Trott, 2014a; Peinemann et al., 2011). This was reflected in the establishment of the 2013 European Commission supported FP7 RECAPT project, which suggested that promising novel technologies with a high level of technology readiness faced significant challenges in their acceptance in the food development value chain. 
Prior studies of eco-innovation adoption have been confined to the agricultural level of the supply chain. Our study focuses on the packaged foods sector, and aims to capture the influence of each key supply chain member on food producers and processors adoption of waste reducing eco-innovations (see Figure 1). This approach is informed by prior studies in agri-food, which highlighted the need to consider technology providers, the supply and demand side of adoption, the role of the retailers (Wheeler, 2008; Long et al., 2015; Mylan et al., 2016), and the important role of the supply chain to innovation (see Table 2).

\section{INSERT FIGURE 1 ABOUT HERE}

Our process of selecting and reviewing studies to identify relevant literature involved two main stages. Firstly, we used key word searches within ISI Web of Science and Google Scholar to generate a list of relevant contributions (Short, 2009). Search terms in the keywords, abstracts or titles included one or more of the following terms: the adoption of eco-innovations, sustainable technologies, waste or food loss reduction, barriers to innovation, product or packaging development. Secondly, the researchers reviewed the articles to identify those providing detail on adoption barriers. We began with studies specifically examining eco-innovation, sustainability or waste, and subsequently reviewed the remaining articles to identify any additional barriers. Potentially pertinent articles identified within the examined papers were also subsequently reviewed.

As a result of our review process, Table 2 incorporates two types of empirical studies. Firstly, barriers identified by prior research specifically examining eco-innovation adoption and sustainable technologies. Secondly, barriers identified by broader innovation and adoption related studies, shaded in grey and identifiable by italics in the column far right. We draw this together into six categories of barriers. Our approach broadly follows prior studies in other processing sectors (Baldwin and Lin, 2001), and the agriculture sector (Long et al., 2015). The remainder of this section explores barriers to adoption in the food sector, followed by a discussion of the wider supply chain.

\section{INSERT TABLE 2 ABOUT HERE}

\subsection{Technology Adoption in Food Processing}

Prior studies highlighted the unique nature of innovation in process industries, and particularly in the food industry (see Grunert et al., 2005; Sarkar and Costa, 2008). Trott and 
Simms's (2017) study of the Doing, Using and Interacting (DUI) innovation mode revealed the important interconnections between equipment and ingredients suppliers, food processors themselves, and the retailer (see Section 2.4). To date, only Bossle et al.'s (2015) study provided initial insights into eco-innovation adoption in the food industry. The only barrier discussed was a lack of institutional support. Broader studies in the food industry have identified a number of other potential barriers, including a lack of leadership and required technical skills, risk aversion, and cost related barriers (see Table 1). We argue that technological eco-innovations face specific challenges to their adoption.

Within process industries the impact of technological product changes on the production process plays an important role in innovation. Prior studies on the adoption of cleaner production technologies reveal that the process costs associated with change result in path dependency (Murphy and Gouldson, 2000; Schwarz, 2008). However the role of production line investments on the adoption of technological eco-innovations incorporated into the product has not been explored. The adoption of waste reducing technologies presents additional challenges due to their potential impact on the core product. Product based ecoinnovations carry specific features, such as the importance of creating links and positive trade-offs between the attribute of environmental protection and other critical factors of competitive products, such as style, design, price and performance (Carrillo-Hermosilla et al., 2010).

\subsection{Technology Adoption in the Food Supply Chain}

The importance of the supply chain to eco-innovation adoption is widely recognised, and is of particular pertinence in agri-food (Mylan et al., 2015; Bossle et al., 2016; Roscoe et al., 2016). Longer supply chains form a challenge to eco-innovation (Table 2; Omta, 2001; Mylan et al., 2014). Indeed, Long et al.'s (2016) study of climate smart technologies identified that the relative distribution of costs and benefits between different supply chain members acted as a barrier to adoption. Yet, prior studies of technology and eco-innovation adoption have largely focused on a single level of the supply chain. By contrast, we contribute to the extant literature through revealing adoption barriers resulting from the technology supplier, food processors, and the retailer. In doing so, our study aims to capture the indirect influence of consumers on technology adoption within the supply chain (see Figure 2).

INSERT FIGURE 2 ABOUT HERE 
Ingredients, raw materials, equipment, packaging, and specialist technology suppliers play an important role in food innovation (Trott and Simms, 2017; Sarkar and Costa, 2008). Yet, few studies have provided insights into the barriers faced by these suppliers. Long et al. (2016) examined the challenges faced by technology providers to the agriculture sector; notably they uncovered the challenges such firms faced in demonstrating the financial or environmental benefits of their technologies. Further, a number of studies have characterised relationships as short-term and cost-orientated (Table 2).

Agricultural firms have received greater attention in the literature. Yet, whilst some agricultural producers are involved in the processing and packaging of produce to be shipped directly to retailers, eco-innovation studies in the agriculture sector have failed to capture the adoption of product and packaging technologies. Prior research provides pertinent understanding of the barriers to eco-innovation adoption in the context of agri-food, such as costs, a lack of awareness and knowledge of environmental practices and technologies, and difficulties in measuring environmental and economic benefits (Long et al., 2015). Short-term adversarial relationships with supermarkets have also been identified as problematic (Simons et al., 2003; Mylan et al., 2015).

Studies examining retailer adoption of new products incorporating eco-innovations have not been conducted. Yet, retailers play a key role in eco-innovation activities in modern food supply chains (Mylan et al., 2015; Chkanikova and Mont, 2015). They frequently form the key actor, controlling the chain. Retailers can utilise their power, size and supply chain position to capture value, and enforce a sustainability agenda (see Mylan et al., 2015; Jones et al., 2005). However, this power can also constrain innovation. Retailer category management $(\mathrm{CM})$, the process through which product adoption and display decisions are made, places the emphasis on the ability of new products and technologies to improve margins, sales and category growth (van Everdingen et al., 2011).

Decisions to adopt eco-innovations are influenced by consumers' environmental concerns (Bossle et al., 2016). Increasing concerns about the environment and levels of packaging waste present firms with an opportunity to positively influence purchase decisions through the adoption of waste reducing technologies (e.g. Bemporad et al., 2012; Plumb et al., 2013). However, the potential impact of new technologies on the product's use, quality and usage life also represent a risk. Likewise, their influence on consumer decision making may be hard for firms to predict. For example, despite concerns over levels of packaging waste, purchasing decisions frequently rely on lay beliefs, inferential cues, and consumers may not spontaneously include sustainability in their purchase decisions (Lindh et al., 2016). 
Consumers also face difficulties to untangle the complex interrelationships between food and packaging waste, and the majority consider packaging a more significant issue than food (Steenis et al., 2017).

\section{Methodology}

The empirical research for this study forms part of a broader collaborative research project undertaken in the UK and the Netherlands. Collaborative research is considered a good means to study and model managerial practices and issues (Shani et al., 2007). The researchers were invited to the organisations to study a problem that was identified as being relevant and critical to both practitioners and researchers (Starkey and Madan, 2001). The research began with initial key informant interviews, the collection of relevant policy documents, and pertinent information from websites. This evolved into a broader collaborative research project, three sponsored PhD projects, and a EU funded project examining technology adoption in the food value chain. The research involved packaging suppliers, technology suppliers, food processors and producers, and retailers, reflecting our initial findings on the critical role of the supply chain in eco-innovation adoption.

\section{INSERT FIGURE 3 ABOUT HERE}

The framework for our case study is depicted in Figure 3. Following our literature review and conceptual framework development, our research followed a longitudinal multiple case study design. The case study research method provides the benefits of enabling the in-depth investigation of a contemporary and complex phenomenon in its real life context, utilising multiple sources of evidence (Yin, 2012). A multiple case methodology was considered to be appropriate for three key reasons. First, the phenomenon to be studied was complex and process in nature, and the events that unfolded would play an important role in building explanations (Pettigrew, 1992). Second, the limited amount of prior research meant that themes and patterns needed to be identified rather than confirmed (Eisenhardt, 1989). Finally, the approach would strengthen the validity of our findings, through comparison across a range of situations and pattern matching, and multiple observations of actions over an extended time period (Eisenhardt, 1989; Yin, 2012). Overall, the method enabled us to respond to the need for deep understanding and local contextualisation (Miles and Huberman, 1994).

For the purposes of this paper, we selected four cases using purposive sampling (e.g. Patton, 1990), with each also selected for its 'intrinsic value' (Stake, 1995). Whilst there are perceived limits to such a research design, we believed it was well suited to generating new 
understanding and for theoretical development, and would enable analytical generalisation (Eisenhardt, 1989; Eisenhardt and Graebner, 2007). The four cases are selected from separate firms. Three technologies originated from UK firms, whilst one is selected from the Netherlands. Table 3 presents our cases representing four separate product categories. We selected technologies that aim to reduce waste in one or more areas of the waste hierarchy principle. Three of the packaging formats involved light weighting, which has been identified as one method of reducing impact and benefitting transportation, and two provided shelf life extending properties, which contribute to reducing food waste (e.g. Coelho et al., 2011). Indeed, around half of the food waste that occurs results from food not being used in time (see Willams et al., 2011). Three cases used recyclable materials, whilst one focused on a biodegradable material. Hence each of the four cases aimed to reduce food and/or packaging waste. Two of the cases involved fruit, vegetables and dairy, which are key categories for high food waste volumes (Williams and Wilkstrom, 2011). The other cases involved sandwiches and raw meats, which are categories with a short shelf life and high waste volumes.

The primary data collection consisted of forty-nine interviews to collect rich empirical data (Eisenhardt and Graebner, 2007). The interviews were undertaken both within each of the firms supplying the technology, food processors and retailers, and other pertinent supply chain partners (see Table 4, Appendix). Before conducting the interviews, following the guidelines of Yin (2012), a profile of each case firm was developed. This was subsequently used to develop an interview protocol, which included a common introduction, description of the research purpose, and a set of specific questions. The protocol was informed by the research questions, the literature, prior research, and the firm's profile.

\section{INSERT TABLE 3 ABOUT HERE}

The evidence from our interviews was transcribed and triangulated with information collected through access to pertinent departments, design briefs and dossiers, and other secondary data (Yin, 2012). The use of multiple sources of evidence, in accordance with principles of 'triangulation' helps to lower subjectivity and improve construct validity (Eisenhardt, 1989). The data analysis process began with an inductive process of category creation (Yin, 2012). Interview transcripts for each case were searched to identify common words, themes, and topics in order to highlight important issues and to classify them according to a common scheme (Piekkari et al., 2010; Yin, 2012). Following this analysis at the level of the individual embedded case, the second stage was a cross-case analysis. The cross case analysis enabled commonalities and differences to be identified, which enables the wider exploration 
of the research problem and theoretical evolution (Eisenhardt and Graebner, 2007). The replication of patterns across a number of cases also increases the robustness of the conclusions and improves analytical generalisation (Miles and Huberman, 1994; Robson, 1993; Eisenhardt and Graebner, 2007). The interpretive process utilised numerous tables searching for patterns, selecting categories and looking for themes and relationships to identify both similarities and differences (Eisenhardt, 1989). This process was iterative and required the researchers to repeatedly read the interview files, notes and other data (Galunic and Eisenhardt, 2001). The clear chain of evidence that resulted from this process aided construct validity (Yin, 2012). To ensure empirical validity in the final stage we compared the emergent patterns to the evidence in each case, to establish closeness of fit (Miles and Huberman, 1994).

\section{Findings and Analysis}

We present our findings in two parts. First, we present each of the cases. This is followed by a cross-case analysis.

\subsection{Case 1: Packaging Supplier Milk Pouch}

Despite being an established format, milk bags have achieved limited success in the UK. Bags possess the advantage of lower material usage, in comparison to cartons and PET bottles. However, their lack of rigidity left them reliant upon jugs for dispensing, and they were also difficult for retailers staff to handle in stores. The new pouch, however, was constructed with a new polymeric formulation that would enable it to maintain an erected bottle-like shape when refrigerated, whilst becoming malleable at room temperature. This made it easier to handle, use and dispose of, whilst minimising material usage.

The team felt the new technology had a good market potential. For dairies it possessed two key advantages. Firstly, projections demonstrated it would "lower unit costs in the longerterm... once economies of scale are achieved, due to lower material usage" [18]. Secondly, handling standard plastic bottles pre-filling was recognised as challenging, and "take up excessive warehouse space" [114]. For retailers there was potential for improvements in the environmental credentials of the milk sold in their stores, and reductions in transportation costs resulting from size and weight reductions.

Research uncovered three key problems. Firstly, dairy farmers and producers margins were typically tight. Unit cost increases were not viable, even in the short term, and the production investments associated with change were considered unaffordable. Secondly, the majority of milk sold in the UK was store branded. Packaging decisions were driven by retailers, whilst 
farmers bore the investment costs. Hence with dairies the bag generated little interest: "we don't have the money and it's not feasible without some joint investment from the retailer.... Most of the milk we sell is branded and the retailer will benefit from the improved environmental credentials, yet we will be the one bearing the cost" [113]. For branded milk "we have to be price competitive with store brands, this makes investment challenging" [112].

The packaging supplier recognised the need to gain retailer support: "the majority of the market for milk packaging is for store brands, and even if we can get a dairy to invest they will need the permission of a retailer to trial the product in their stores... they hold the key to acceptance" [16]. The meetings with retailers were not positive: "it's the responsibility of our dairies to progress our packaging.... we feel consumers are satisfied with existing containers and there's no specific need to push a trial of the new technology" [14]. Indeed one retailer suggested "..if others change then we would consider changing too". For retailers the technology also held risks, if packs split or damaged too easily.

\subsection{Case 2: AMAP for Soft Fruits and Vegetables}

This case involved the adoption of an Advanced Modified Atmosphere (AMAP) technology to extend product shelf life. The technology lasered precisely measured holes to let produce breathe, while considering fruit respiration rates. Whilst foils with different degrees of permeability already existed, precisely lasered holes ensure better respiration control (i.e. $\mathrm{O} 2$ and $\mathrm{CO} 2$ balance). The respiration rate of foods is category dependent, and varies by product type, seasonality, and temperature. To ensure ease of implementation, use and affordability, the technology provider developed a compact and affordable respiration meter and software to automate the process of creating the correct size of holes. The technology was compatible with existing punnets, base foils, for the packaging line.

The firm struggled to gain acceptance. The responsibility for technology investments formed a hurdle to adoption, combined with buyer uncertainty over its performance in each product category, and changes to existing working routines. The MD decided to actively seek a "killer-application" [117]. Ultimately the soft fruits category was identified. This category was known for high food waste, and supermarkets regarded it as a competitive point-ofdifference. The majority of produce was co-packed or packaged by the producer on fruit and vegetable farms with limited technology knowledge.

Despite these efforts the supplier was unsuccessful. Discussions revealed three key challenges. First, success depended on supply chain collaboration; "from both ends [grower and retailer], it is a chain project, in which you have to tie the source and endpoint together: 
it makes no sense to contact a supplier [in the middle] if the retailer is not on board" [117]. Secondly, retailers would only be enthusiastic when the financial and customer benefits were "proven eminent and abundant, and when all sourcing companies would agree with the investments in the technology" [117]. Finally, all soft fruits sourcing companies needed to be on board prior to the trial, including those not participating who were likely to temporarily experience a loss of competitive advantage with the introduction of the technology.

Following many discussions, the technology provider finally identified an innovative retailer and an agreement was reached for all key partners to collaborate on a trial. During the trial, sales and waste of produce with the AMAP were compared to: a) standard packaged produce and b) produce packaged with competing scavenger technology. Shelf life of raspberries increased from five to ten days, and strawberries from four to eight days. Instore waste reduced by $50 \%$ and $95 \%$ for strawberries and raspberries respectively, resulting in "double-digit sales growth" [125]. The technology was adopted and further trials were subsequently conducted on different foods. This generated interest from other retailers, and they too began to trial and dedicate shelf space to AMAP packed produce. The technology is now used in over 15 countries with over 200 fruit and vegetable products.

\subsection{Case 3: Biodegradable lightweight MAP packaging format for raw meat}

A new biodegradable plastic material enabled the production of a lightweight packaging format for meats. Using a unique process, meat was tightly wrapped in the biodegradable film with a small amount of added modified atmosphere gases, and a simple label was applied. This minimised the packaging whilst resulting in small increases in the use by date. The technology offered customers the opportunity to "differentiate raw meats on the basis of packaging... currently if you walk down a meat aisle they are just full of meat trays which are excessive and either not recyclable or not easily so" [I30]

The majority of meat was supermarket branded. Hence the manufacturer approached both supermarkets and their suppliers to establish a trial. Suppliers indicated some interest; "the potential for long-run cost savings is attractive.. [as well as packaging] taking up less space in our facilities" [137]. Yet, their interest was limited: "format decisions are down to the retailer, as essentially it's their product... for us the prospect of changing represents a large investment and disturbance to our operations" [138]. Equipment investments represented a challenge: "..it will benefit the retailer's own brand meat sales, but we will be the ones who have to invest" [I39]. Even branded meat suppliers were unable to independently adopt. Retailer involvement was required to conduct distribution and store trials, and analyse the impact on their products. 
Marketing and category management personnel were concerned over the potential to damage sales through "the minimal packaging... which will compromise shelf presence" [137]. Further, "consumers probably won't like the feeling of effectively directly handling the meat, whereas a tray takes away that feeling" [135]. Finally, retailers were unwilling to jointly invest in new equipment with suppliers: "for us the format carries several risks and the supplier would benefit from improved unit costs, so I am not convinced by the business case" [I34].

Following over twelve months of discussions a trial was negotiated: "one supermarket was more open to innovation and proactive about being green,.. it was very hard to get them on board but we finally achieved it" [128]. The trial was initially confined to four products: chicken breasts, thighs, beef mince and several joints. Secondly, the equipment would initially be supplied without charge, until the format was proven at which point the retailer and producer would jointly invest. The producer would purchase the packaging and provide trial batches to the retailer for regional trials. "I had to put my neck on the line several times to bring this trial to the market... and we agreed to undertake extensive in-store communications to overcome the potential negative consumer reaction to the format" [131].

The packaging team and supplier were delighted with the results. However, the marketing and category teams had concerns and wanted to discontinue the packaging: "Marketers were concerned over excessive meat juices and blood in the packaging" [135], which had also been noted in focus groups. Further, whilst there was no evidence that it had harmed sales, there were concerns over some discoloration that had occurred on beef mince and chicken thighs. These products were withdrawn for further R\&D, whilst absorbent gauze pads were added to the joints. Subsequently the packaging manufacturer was approached by other retailers, who had been secretly monitoring the results, and wished to undertake trials.

\subsection{Case 4: Lightweight Material for WRAP style sandwich packaging}

This case examined a new lightweight material that could be used to package wrap style sandwiches, using a single biodegradable substrate. In order to establish a trial, the manufacturer approached several branded sandwich producers and retailers to whom it already supplied packaging for sandwich and lunchtime ranges. Following many months, the supplier identified a retailer that was due to undertake a rebranding and line relaunch, with several new products, and had thus been looking for a format to pack its tortilla wrapped products alongside a new lettuce based wrap. 
The packaging team were "attracted by the minimalistic format... we like the idea that the product can become the hero, with minimal packaging and labelling" [145]. However, Marketing put up significant resistance "how do we get across the product and our positioning if there's almost nothing to the packaging... I am not sure how far we should take the concept of minimal packaging" [147]. It became clear there were differences in perceptions: "We don't see it as pioneering, but the category team does" [146].

After extensive discussions, kitchen tests and consumer focus groups were agreed. The supplier provided a customised version of the packaging; this featured a small label and the plastic wrapper unfolded into a virtual plate to eat the product from. Marketing were concerned with the test results that "consumers don't know what to do with the packaging" [144]. The Head of Packaging had to "exert great effort to push the new development.... there was a great deal of concern the packaging would hinder the product's sales" [145], a compromise was agreed using "display boards at the point of sale to provide enough information and increase the shelf presence" [145]. It was also decided that the product would be displayed vertically in refrigerators in an attempt to regain some of the lost shelf impact. The new format was trialled in several stores.

The trials produced mixed results. The shelf life was as expected, but modifications were required to the format to provide sufficient protection in transit. Whilst the packaging manufacturer was confident that this could be achieved, the retailer decided to discontinue: "Ultimately we adopted a compromised solution, much like the packaging used on our competitors' products.... whilst it's a poorer solution from an environmental waste perspective, it was seen as proven, less risky and 5-10\% lower in cost" [145].

\section{Cross Case Analysis}

The results of our case studies demonstrate complex interrelated barriers inhibiting the adoption of waste reducing technological eco-innovations. Our analysis focused on barriers within the food firm, as the technology adopter, whilst uncovering how the activities and decision-making of other supply chain partners influences their adoption decision-making. Our initial conceptual framework captured the key supply chain partners influencing technology adoption, and facilitated our exploration of barriers. Building upon this, the preceding discussions enable us to develop an enhanced conceptual framework that captures the key barriers described above and identifies how each barrier relates to the different supply chain levels (see Figure 4). 
The center of the Figure 4 captures the key barriers within the food firm itself. Respectively, the columns to the left and right reflect how the activities and decision-making within the retailer and technology provider present further barriers within the technology adopter. Our framework demonstrates the interrelatedness between each supply chain level in ecoinnovation adoption. The combination of these complex and interrelated barriers has not been captured by prior research in the food industry or the agri-food supply chain (Bossle et al., 2015; Long et al., 2016).

\section{INSERT FIGURE 4 ABOUT HERE}

A. Switching Costs and Unit Cost Implications: Our results highlighted the significance of production equipment investments and unit cost implications. Product changes require process changes. Firms sunk costs in their existing production line represent a key barrier (Murphy and Gouldson, 2000; Schwarz, 2008): "it is cheaper to lightweight existing packaging, than it is to switch to a new format, as there's more investments involved" [19]. The installed base was an obstacle in Cases A, C and D. In the case of AMAP, it was compatible with existing packaging lines - "our laser can be mounted on a foil winding machine, this facilitated market introduction" [117]. Yet, the technology provider still had to "...develop a new, smaller and simplified version [of the respiration meter] because they received feedback about the high costs" [117]. Even where technologies were likely to produce long-run cost savings; for example, due to reduced materials usage, short-term increases in costs were hard for food processors to bear. The following discussions reveal how retailer "price pressures" [I37], combined with adversarial relationships, compounded this barrier.

B. Characteristics of Waste Reducing Technologies and their Impact on the Product: Waste reducing technologies were frequently "...not 'silent' to the consumer" [130]. For decisionmakers, adoption held the potential to impact on the core product (e.g. CarrilloHermosilla et al., 2010), influencing consumer product use, perceptions of quality and value, POS advertising, and ultimately the consumers purchase and repeat purchase decisions. This resulted in "...significant level of commercial risk". By contrast, this barrier was not evident for AMAP, where the commercial risk was limited as in most countries soft fruit was already closed with foils. These findings reveal that whilst waste reduction and sustainability are seen as concerns to consumers, retailers and brand owners are concerned with the risks they present. 
C. Retailing and Point of Sale Risks: Changes to the product and packaging often influence retailer product displays and shelf positioning decisions (Simms and Trott, 2014a). For the food processor this presented a significant risk. Whilst AMAP had limited impact on display, in the other cases food processors were concerned that changes may lead to retailer's considering change to the product's shelf positioning or even a decision to delist the product. A second linked factor was the impact of adopting the technology on both the food and its retailing, creating a need for distribution and retail trials to ensure safety and efficacy. Hence it was "..necessary to involve retailers in decision-making" [I11]. In the case of both the milk bag, and particularly the meat technology, this was complicated by "retailers concerns over the potential negative impact of these technologies on the product's display and their ability to decrease shelf presence" [140]. Hence both could negatively impact on category sales.

D. Lack of Consumer Market Opportunity: Retailer decision-making was “...largely influenced by the potential impact of product changes on category performance. Technologies are analysed in terms of their potential to increase category margins or result in category growth" [I10] (e.g. van Everdingen et al., 2011). Whilst prior research highlights the increasing importance of waste to consumers (Bemporad et al., 2012; Plumb et al., 2013), such technologies were not seen to hold great potential: “... I just don't see consumers paying more or buying larger volumes because it produces less waste" [113]. Furthermore, decision-makers were also suspicious of consumers' intentions versus actual purchase behavior "in store I don't think it influences purchase behavior as much as other things that may add value to such product improvements and packaging designs" [147]. Food-waste reducing technologies presented little opportunity, as consumers "focused on packaging waste over food waste" [116].

E. Simultaneous Food Processor-Retailer Adoption: The combination of the impact of new technologies on the product's retailing, concerns over consumer demand, and the need for distribution and shelf trials, created a need for simultaneous adoption by both the retailer and food processor in conjunction. This represented a significant challenge, as "from both ends [grower and retailer], it is a chain project, in which you have to tie the source (food supplier) and endpoint (retailer) together: it makes no sense to contact a supplier [in the middle] if the retailer is not on board" [12]. Packaging suppliers had to get their technologies accepted by both food firms and retailers. Yet, they struggled to communicate directly with retailers. Their point of contact was typically the food supplier. 
F. Poor Communications and Adversarial Relationships: Communications between retailers and food processors can be characterised as short-term transaction orientated, adversarial and cost focused (e.g. Caiazza et al., 2014): "The majority of discussion about trying to reduce the price we can sell our product to them for.... when we raise the topic of improving environmental impact they aren't that interested. It's down to us, but it mustn't increase what they pay" [139]. These issues were also evident for some technology suppliers: "most of our existing packaging is commoditised, trying to discuss introducing something that will raise cost is challenging... we find it hard to communicate meaningfully with our supply chain partners" [12]. Poor communications, combined with interlinked adoption-decision making, represented a significant adoption barrier.

G. High Risk and Unproven Technologies: Both food firms and retailers were concerned over the risk of new technologies. The retailer's risk averse decision-making (Trott and Simms, 2017) resulted in a "reluctance to adopt products with new technologies that have not been proven in use" [125] and "it had to deliver a key commercial benefit, so whether that is reducing waste in-store or increasing availability, they should also make sure that they don't get any increase in customer complaints" [126]. Safety in food products is critical. The implications of this were noted by I33: "this results in a Catch 22, they do not want to adopt it until another retailer has shown it's a safe bet, but if none of them will adopt it then this can never happen". Both the AMAP and meat packaging cases revealed that once a new technology had been adopted by a food processor and sold by a retailer, other potential customers soon followed.

H. Lack of Equal Distribution of Costs and Benefits: Building upon Long et al.'s (2015) initial insights, food processors were concerned by an unfair distribution of costs. This related to both “..unit costs and retailer's lack of willingness to invest in technologies" [128]. Retailers overlooked the impact of immediate cost increases upon the supplier. Food processors had little control: "we have little influence on the retailer, investments are considered our responsibility". In the case of own brand product's: “... it's not really our product, it's the retailer's, so we don't see a need to drive change. But the retailer doesn't really take the initiative" [138]. Within the AMAP case, the supplier identified a retailer able to compensate the producer for the cost as "sourcing companies bought the technology and received a compensation from the retailer per pack" [117]. Further, producers and co-packers perceived the technology provider to benefit the greatest from adoption: "the grower did not want to buy the machine, as he argued that we had to prove something, not he" [117]. Indeed, "having absorbed the technology development 
costs, we can't just hand over free equipment... we already have to be prepared for a long ROI and low margins" [11].

I. Lack of required Environmental and Production Capabilities: Building upon prior studies (Simms and Trott, 2014b; Avermaete et al., 2004), our findings revealed two problems resulting from a lack of capabilities. First, food processors have inadequate capabilities to assess the investments in adopting new technologies: "they often assume there will be a large cost, and do not really analyse it" [I3]. Further, both food processors and retailers had limited environmental capabilities. Whilst they felt technologies presented little opportunity, they "lacked the experience or insight to fully assess the opportunity" [116].

J. Lack of Consistent Environmental Guidance: A final factor was a perceived inconsistency in the guidance that food processors received from both regulatory bodies, governments and retailers on environmental priorities. It was difficult for food processors to assess what types of technologies they should prioritise. Long-term investments were therefore perceived as challenging, due to potential changes in guidance: "A few years ago WRAP was pushing us to reduce packaging weight, which led many manufacturers to move to plastics... now we are being penalized for plastic's use" [144], confirming findings from prior studies (Bossle et al., 2006; Long et al., 2016).

\subsection{Discussion}

We presented four cases of eco-innovations. Whilst costs, inconsistencies in environmental guidance and a lack of capabilities have been identified by prior studies of eco-innovation adoption (e.g. Bodanski, 2012; Bossle et al., 2016), our analysis demonstrated a number of unique adoption barriers in the food processing sector. We also uncovered the interconnections between each supply chain member and the adoption decision-making of food firms.

The interrelationships in decision-making across the supply chain increases the complexity of technology adoption (Figure 4). The specific characteristics of the food industry (e.g. Trott and Simms, 2017; Grunert et al., 2008) and the waste reducing technologies create a number of unique adoption barriers. The technologies in our study frequently required retail and distribution trials. Significantly, their acceptance required them to be proven in use, due to potential safety and commercial risks. For food processors this means they are unable to adopt technologies without retailer agreement. A different set of problems faced technology suppliers. They must gain commitment to trial new technologies from both food processors and retailers. This led to complex and interrelated decision-making across supply chain 
members. Given the known poor communications in agri-food supply chains (e.g. Mylan et al., 2015; Bogdanski, 2011), these findings help to explain the challenges new technologies face (e.g. RECAPT Report, 2014; Peinemann et al., 2011).

Long et al. (2016) provided initial insights into a lack of equal distributions of costs and benefits as a barrier at the agriculture level of the supply chain. Our cases reveal that waste reducing technologies required investments and held the potential for increases in unit costs. Yet, retailers were unwilling to jointly invest in new technologies and supply chain relationships were characterised as adversarial. This was particularly evident in the case of the Milk Bag, which is yet to reach the market. Dairies were unable to obtain joint investment from retailers and struggled to secure shelf trials for the new technology. The barrier presented by retailer's unwillingness to invest in new technologies was compounded by poor margins amongst food processors (see Trott and Simms, 2017).

Investment and unit cost barriers were compounded by a perceived lack of market opportunity for waste reducing technologies. Despite recognition of consumer's increasing concerns over the environment, both retailers and food processors perceive a lack of consumer preference for products that lower waste (e.g. Bemporad et al., 2012; Plumb et al., 2013). In particular consumers were seen to be insufficiently informed about the complexities of food and packaging waste, and at the point of sale other factors had greater influence in their purchase decisions (e.g. Steenis et al., 2017; Cox and Downing, 2007).

\section{Conclusions, Implications and Future Research}

This research sought to identify the key barriers inhibiting the adoption of technological ecoinnovations in the food industry, incorporating the influences of both retailers and technology providers in adoption decision-making. The findings of our cases demonstrate the usefulness of our conceptual approach for assessing barriers in the food processing industry. We revealed that despite their potential technologies that reduce waste face a number of unique challenges in reaching the market. Our study has generated insights pertinent to both scholars, practitioners and policy makers.

\subsection{Scientific Contributions to the Literature}

Prior eco-innovation adoption studies have either focused on agricultural firms (e.g. Long et al., 2015) or failed to specifically examine the adoption of technologies (e.g. Bossle et al., 2015). Our study examined the barriers to the adoption of waste reducing eco-innovations in food processing sector. Due to the significant environmental impacts of food and packaging waste understanding the specific barriers to the adoption these technologies is critical. The 
analysis of our cases revealed ten barriers to technology adoption. We have provided a first assessment of technological eco-innovation adoption barriers within two European Countries.

The second contribution of our article is a framework capturing the interrelationships between eco-innovation adoption barriers within the food supply chain. Building upon Mylan et al.'s (2014) contributions to the environmental supply chain literature, our framework reveals the high degree of interrelatedness between product adoption making within retailers and technology adoption within food processors. Critically, we have revealed that the retailer's willingness to adopt product's with new eco-innovations forms a prerequisite to the supplier's to adoption of new innovations. This requirement results from the nature of the food processing industry, the significant influence of retailers, and the need for store trials of new products (e.g. Trott and Simms, 2017; Caiazza et al., 2014). The requirement for simultaneous adoption has not been captured by prior research.

Our third contribution is to the study of Mylan et al. (2015) who suggested that the supermarket retailers power provides them with the opportunity to stimulate 'upstream' improvements in environmental performance. Our findings illustrate that in the case of ecoinnovation adoption within the food processing sector, the retailer's emphasis on improvements in category performance (van Everdingen et al., 2011) frequently acts as a barrier to adoption. New technologies were not only seen to present limited market opportunity, they also presented a commercial risk due to their potential impact on the product's safety and its display at the point of sale.

\subsection{Implications}

Our research identified a number of implications for both firms and policy makers. The interconnections between each supply chain member and the adoption decision-making of food firms has significant implications for policy makers. Building on Long et al. (2016), our findings reveal that measures must be taken to create new mechanisms that facilitate supply chain communications, joint investments and a longer-term approach to decision-making. For technology providers, their eco-innovations frequently require retail and distribution trials, and must be proven in use to gain acceptance. For food suppliers, their decision to adopt is heavily influenced by the retailer; yet, retailers' decisions are primarily influenced by cost and category performance. Our cases also provide initial insights into how innovation managers may tackle these adoption barriers. The successful AMAP and meat packaging cases both highlighted the identification of supply chain partners that were more innovative and proactive in pursuing environmental improvements. In the case of AMAP, the 
identification of a product application in which the technology had a particularly pronounced effect was also key.

Retailer's represent a key supply chain actor in stimulating eco-innovation (Mylan et al., 2015). Yet, our cases reveal little emphasis on sustainability within their decision-making. Interventions must therefore take account of each supply chain level, and how they will influence adoption behavior in the food industry. In particular, policies must place greater pressure on retailers to ensure improvements in food and packaging waste. For example, our results suggest that the polluter pays principle is likely to be of limited effectiveness, as it does not act as an incentive to the retailer. Finally, our findings identify a need for policies and action by government, NGO's and the key members of the food supply chain to improve understanding and increase consumer awareness of food and packaging waste in order to stimulate the adoption of new technologies.

\subsection{Limitations and Future Research}

Our research has provided new understanding of the barriers to eco-innovation adoption within the food processing sector. As with all research it has several limitations. Future research should aim to further our understanding in several key areas.

Firstly, it should be recognised that our study is exploratory in nature and was limited to four cases, including both successful and unsuccessful technologies. There is a need for further comparative studies examining successful and failed technologies to: (i) enhance our understanding of each barrier, (ii) identify other barriers that may exist, and (iii) validate our results through larger samples. Secondly, our findings identified two mechanisms through which the barriers were tackled. These mechanisms warrant further investigation. Future studies should also deepen our understanding of other potential solutions to each of these adoption barriers. Third, our cases examined only four packaged food product categories. Mylan et al. (2015) suggested that retailers interest in eco-innovation differs by category, hence there is a need for studies examining eco-innovation adoption across a wider range of categories. The barriers identified in the present study guide the way forward for this research, the analysis of further cases would further enrich our understanding. Fourth, our study is limited to waste reducing technologies. Future research should explore other ecoinnovations within the food processing sector.

Fifth, our study aimed to provide insights into the influence of retailers product adoption decision-making on food processors technology adoption. Future studies should further examine the retailers role. Finally, we suggest a need for research examining consumer 
adoption of products. Studies are required to understand the consumer's decision-making on products that reduce food and packaging waste, including experiments examining how purchasing behavior is influenced by technologies that reduce waste. Studies should also examine potential mechanisms to ensure environmental awareness translates into purchasing behaviors.

\section{References}

Avermaete, T., Viaene, J. Morgan, E.J., Pitts, E. Crawford, N., and Mahon, D. 2014. Determinants of product and process innovation in small food manufacturing firms, Trends in Food Sci. and Technol., 15, 474-483.

Bailey, I., 1999. Flexibility, harmonization and the single market in EU environmental policy: the packaging waste directive. J. Common Mark. Stud. 37, 549-571.

Baldwin, J. and Lin, L., 2001. Impediments to advanced technology adoption for Canadian manufacturers. Res. Pol. 31, 1, 1-18.

Bemporad, R., Hebard, A., Bressler, D., 2012. Re:Thinking Consumption. Consumers and the Future of Sustainability. BBMG, GlobeScan and SustainAbility. Retrieved from: https://globescan.com/rethinking-consumption-consumers-and-the-future-of-sustainability/

Bhaskaran, S., Polonsky, M., Cary, J. and Femandez, S., 2006. Environmentally sustainable food production and marketing: opportunity or hype. Br. Food J. 108, 8, 677-690.

Bogdanski, A., 2012. Integrated food-energy systems for climate-smart agriculture. Agric. Food Secur. 1, 9.

Bossle, M.B. De Barcellos, M.D. Vieira, L.M. 2016. Why food companies go green? The determinant factors to adopt eco-innovations. Br. Food J. 118, 6, 1317-1333.

Bovea, M.D., Serrano, J., Bruscas, G.M., Gallardo, A., 2006. Application of life cycle assessment to improve the environmental performance of a ceramic tile packaging system. Packag. Technol. And Sci. 19, 2, 83-95.

Brunke, J.-C., Johansson, M. Thollander, P., 2014. Empirical investigation of barriers and drivers to the adoption of energy conservation measures, energy management practices and energy services in the Swedish iron and steel industry. J. of Clean. Prod. 84, 1, 509525.

Buzby, J.C., Hyman, J., Stewart, H., Wells, H.F., 2011. The Value of Retail- and ConsumerLevel Fruit and Vegetable Losses in the United States. J. of Consum. Aff. Fall. 492-515.

Caiazza, R., Volpe, T. and Audretsch, D., 2014. Innovation in agro-food chain: Policies, actors and activities. J. of Enterp. Communities: People and Places in the Glob. Econ. 8, 3, 180-187. 
Carillo-Hermosilla, J., del Rio, P. and Konnola, T., 2010. Diversity of eco-innovations: reflections from selected case studies, J. of Clean. Prod., 18, 1073-1083.

Coelho, T.M., Castro, R., Gobbo Jr., J.A., 2011. PET containers in Brazil: opportunities and challenges of a logistics model for post-consumer waste recycling. Resour. Conserv. Recycl. 55, 291-299.

Chkanikova, O. and Mont, O., 2015. Corporate supply chain responsibility: drivers and barriers for sustainable food retailing. Corp. Responsib. and Environ. Mang. 22, 65-82.

Da Cruz, F. N., Ferreira, S. Cabral, M. Simoes, P., Marquez, R.C., 2014. Packaging Waste Recycling in Europe: is industry paying for it?, Waste Mang. 34, 298-308.

Cullen, R., Forbes, S.L., Grout, R., 2013. Non-adoption of environmental innovations in wine growing. N.Z. J. Crop Hortic. Sci. 41, 41-48.

Del Borghi, A., Gallo, M., Strazza, C., Del Borghi, M., 2014. An evaluation of environmental sustainability in the food industry through life cycle assessment: the case study of tomato products supply chain. J. Clean. Prod. 78, 121-130.

Dijk F. 2000. Sustainability for retailers. European Retail Digest. 27, 19-23.

Eidt, C., Hickey, G., Curtis, M., 2012. Knowledge integration and the adoption of new agricultural technologies: Kenyan perspectives. Food Sec. 4, 355-367.

Eisenhardt, K. (1989) Building theories from case study research. Acad. of Mang. Rev. 14, 4, 532-550.

Eisenhardt, K. and Graebner, M.E., 2007. Theory building from cases: opportunities and challenges. Acad. of Mang. J. 50, 1, 25-32.

Esberg, L., Burt, S., Pearse, H., Glanz-Chanos., 2016. Retailers and technology-driven innovation in the food sector: caretakers of consumer interests or barriers to innovation? Br. Food J. 118, 6, 1370-1383.

Euromonitor, 2018. Packaged Food Market Statistics Database. Euromonitor International. Euromonitor, 2018. Packaged Food in the United Kingdom. Euromonitor International. European Commission, 2014. In: Commission (Ed.). Climate Action: Low Carbon Technologies. EU Commission, Brussels.

van Everdingen, Y.M. Sloot, L.M., van Nierop, E., Verhoef, P.C., 2011. Towards a Further Understanding of the Antecedents of Retailer New Product Adoption. J. of Retailing, 87, 4, 579-597.

FAO, 2009. How to feed the world in 2050. Food and Agriculture Organization (FAO), United Nations, Rome, Italy Foresight Project on Global Food.

Galunic, D. C., \& Eisenhardt, K. M. 2001. Architectural innovation and modular corporate forms. Acad. of Mang. J., 44, 1229-1249.

Graham-Rowe, E., Jessop, D.C., and Sparks, P. 2014 Identifying motivations and barriers to minimising household food waste. Resour., Conserv. and Recycling. 84, 15-23. 
Guerin, T.F. 2001. Why sustainable innovations are not always adopted. Resour., Conserv. and Recycl. 34, 1-18.

Grunert, K.G., Jeppesen, L.F., Jespersen, K.R., Sonne, A.-M., Hansen, K., Trondsen, T., 2005. Market evaluation of value chains: a conceptual framework based on four case studies from the food industry. European J. of Market. 39, 428-455.

Hall J. 2001. Environmental Supply-Chain Innovation. Green. Manag. Int. 35, 105-120.

Hanssen, O.J., Møller, H., Svanes, E., Schakenda, V., 2012. Life cycle assessment as a tool in food waste reduction and packaging optimization - packaging innovation and optimization in a life cycle perspective. In: Life Cycle Assessment Handbook. Wiley, New York, 348-364.

Hart, S.L., Dowell, G., 2011. The natural resource based view of the firm: fifteen years after. J. of Manag. 37, 1464-1479.

Horbach, J., Rammer, C. and Rennings, K., 2012. Determinants of eco-innovations by type of environmental impact - The regulatory push/pull, technology push and market pull, Ecological Econ., 78, 112-122.

Janssen, E. and Swinnen, J., 2017. Technology adoption and value chains in developing countries: evidence from dairy in India, Food Pol., in press corrected proof.

Johnson S.P. and Corcelle, G., 1997. The environmental policy of the European Communities. 2nd ed. London, UK: Kluwer Law International.

Jones, P, Comfort, D., Hillier, D., 2005. Corporate social responsibility and the UK's top ten retailers. Int. J. of Retail \& Distrib. Mang. 33: 882-892.

Kemp, P. and Pontoglio, S., 2011. The innovation effects of environmental policy instruments - a typical case of the blind men and the elephant? Ecol. Econ. 72, 28-36.

Leach, M., Rockström, J., Raskin, P., Scoones, I.C., Stirling, A.C, Smith, A., Thompson, J., Millstone, E,, Ely, A., Foke, C. and Olsson, P., 2012. Transforming innovation for sustainability. Ecol. and Society, 17, 2, p. 11.

Lindh, H., Williams, H., Olsson, A., Wikstrom, F., 2016. Elucidating the indirect contributions of packaging to sustainable development - a terminology of packaging functions and features. Packag. Technol. Sci. 29 (4/5), 225-246.

Long, T.B., Blok, V. and Coninx, I., 2016. Barriers to the adoption and diffusion of technological innovations for climate-smart agriculture in Europe: evidence from the Netherlands, France, Switzerland and Italy, J. of Clean. Prod., 112, 9-21.

Lowe, P., Phillipson, J. and Lee, R.P. (2008), "Socio-technical innovation for sustainable food chains: roles for social science", Trends in Food Sci. and Technol., 19, 5, 226-233.

Luijsterburg, B. and Goossens, H., 2014. Assessment of plastic packaging waste: Material origin, methods, properties. Resour., Conserv. and Resour., 85, 88-97. 
Luken, R. and Rompaey, F.V., 2007. Drivers and barriers to environmentally sound technology adoption by manufacturing plants in nine countries, J. of Clean. Prod., 16,1, 67-77.

Luthra, S., Kumar, S., Kharb, R., Ansari, M.F., Shimmi, S.L., 2014. Adoption of smart grid technologies: an analysis of interactions among barriers. Renew. Sustain. Energy Rev. 33, 554-565.

Lybbert, T.J. and Sumner, D.A., 2012. Agricultural technologies for climate change in developing countries: policy options for innovation and technology diffusion, Food Pol., 37, 114-123.

Mariesse, A.E., van Sluisveld, Worell, Ernst, 2013. The paradox of packaging optimization a characterization of packaging source reduction in The Netherlands, Resour.. Conserv. Recycl. 73, 133-142.

Marsh, K., Bugusu, B., 2007. Food packaging roles, materials and environmental issues. J. of Food Sci., 72, 3, 39-55.

Miles, M.B. and Huberman, A.M. (1994), Qualitative Data Analysis: An Expanded Sourcebook, Sage, Thousand Oaks, CA.

Montalvo, C., 2008. General wisdom concerning the factors affecting the adoption of cleaner technologies: a survey 1990-2007, J. of Clean. Prod., 16,1, 7-13.

Morand, F., Barzman, M., 2006. European Sustainable Development Policy (1972-2005): Fostering a Two-dimensional Integration for More Effective Institutions. IDARI working paper, RTD project QLRT-2002-02718. Eco Innovation (Galway, Ireland)/Humbolt University of Berlin, Ireland/Germany.

Murphy J, Gouldson A. 2000. Environmental policy and industrial innovation: integrating environment and economy through ecological modernization. Geoforum, 31, 33-44.

Mylan, J., Geels, F.W., Gee, S. McMeekin, A. and Foster, C., 2015. Eco-innovation and retailers in milk, beef and bread chains: enriching environmental supply chain management with insights from innovation studies, J. of Clean. Prod., 107, 20-30.

OECD (Organization for Economic Co-operation and Development), 2013. Waste Statistics, Environment Statistics. http://www.oecd.org/statistics/ (Retrieved 28/08/2016).

Omta, S.W.F., 2001. Chain and network science: a research framework. Chain Netw. Sci. 1 (1), 1-6.

Parfitt, J., Barthel, M., and Macnaughton, S., 2010. Food waste within food supply chains: quantification and potential for change to 2050. Philisophical Transations of the Royal Society B. 365, 3065-3081.

Patton, M.Q., 2005. Qualitative Research. John Wiley \& Sons, Ltd. 
Peinemann, K.V., Nunes, S.P. and Giorno, L., 2011. Membranes for Food Applications, Membrane Technol., Wiley-VCH.

Pettigrew, A.M., 1992. The character and significance of strategy process research, Strategic Mang. J., 13, 5-16.

Piekkari, R., Plakoyiannaki, E. and Welch, C., 2010. 'Good' case research in industrial marketing: insights from research practice, Ind. Marketing Mang., 39, 109-117.

Plumb, A., Downing, P., Parry, A., 2013. Final Report: Consumer Attitudes to Food Waste and Food Packaging. WRAP, UK. ISBN: 978-1-84405-465-7. Accessed at (30/6/2018): www.wrap.org.uk.

Poyatos-Racionero, E., Ros-Lis, J.V., Vivancos, J-L., Martinez-Manez, R. 2018. Recent Advances on intelligent packaging as tools to reduce food waste, J. of Clean. Prod., 172, 3398-3409.

Quested, T., Johnson, H. 2009. Household Food and Drink Waste in the UK. Waste \& Resources Action Programme (WRAP).

RECAPT Final Report, 2014. Retailer and Consumer Acceptance of Promising Novel Technologies and Collaborative Innovation Management (retrieved 22/2/2018): https://cordis.europa.eu/docs/results/289/289755/final1-recapt-final-report.pdf

Robson, C. 1993. Real World Research. Blackwell.

Roscoe, A, S., Cousins, P.D. and Lamming, R.C., 2016. Developing eco-innovations: a three-stage typology of supply networks, J. of Clean. Prod., 112, 1948-1959.

Santini, C., Cavicchi, A. and Casini, L., 2013. Sustainability in the wine industry: key questions and research trends. Agricultural and Food Economics. 1, 9, 1-14.

Sarkar, S. and Costa, A.I.A., 2008. Dynamics of open innovation in the food industry, Trends in Food Sci. and Technol., 19, 574-580.

Schwab, J., 2010. Environmental Protection Agency (EPA). Office of Solid Waste and Emergency Response (OSWER). Washington, DC.

Schwarz HG., 2008. Technology diffusion in metal industries: driving forces and barriers in the German aluminium smelting sector. J. of Clean. Prod. 2008, 16, 1S1, 37-49.

Shani, A.B., Mohrman, S.A. Pasmore, W.A., Stymne, B. and Adler, N. (Eds.). 2007. Handbook of Collaborative Management Research, Sage Publications.

Short, J. 2009. The art of writing a review article. J. of Manag. 35, 1312-1317.

Stake, R.E., 1995. The Art of Case Study Research. Sage.

Starkey, K. and Madan, P., 2001. Bridging the relevance gap: aligning stakeholders in the future of management research. Br. J. of Mang., Special issue 1, 3-26.

Statistica, 2018. Market Value of Packaged Food in the United Kingdom 2013-2018: (retrieved 8/4/18): https://www.statista.com/statistics/491366/packaged-food-unitedkingdom-uk-market-value/ 
Steenis, N.D. van Herpen, E. van der Lans, I., Ligthart, T.N., van Trijp, H.C.M. 2017.

Consumer response to packaging design: The role of packaging materials and graphics in sustainability perceptions and product evaluations, J. of Clean. Prod., 162, 286-298.

Simms, C. and Trott, P., 2014. a. Barriers to the Upgrade Cycle in a commodity process industry: evidence from the UK packaging industry, R\&D Mang., 44, 2, 152.

Simms, C. and Trott, P., 2014. b. Conceptualising the management of packaging within new product development: a grounded investigation in the UK fast moving consumer goods sector, Eur. J. of Mark. 48, 11/12, 2009-2032.

Simons, D., Francis, M., Bourlakis, M., Fearne, A., 2003. Identifying the determinants of the value in the UK red meat industry: a value chain analysis approach. Chain Netw. Sci. 3, 2, 109-121.

Trott, P. and Simms, C. 2017. An examination of product innovation in low- and mediumtechnology industries: cases from the UK packaged foods sector. Res. Pol. 46, 3, 605623.

Tukker, A., Jansen, B., 2006. Environmental impact of products: a detailed review of studies. J. of Ind. Ecol., 10, 3, 159-182.

Visschers, V.H.M., Wickli, N. and Siegrist, M. 2016. Sorting out food waste behaviour: A survey on the motivators and barriers of self-reported amounts of food waste in households, J. of Environ. Psy. 45, 66-78.

Wheeler, S.A., 2008. The barriers to further adoption of organic farming and genetic engineering in Australia: views of agricultural professions and their information sources, Renew. Agric. and Food Syst. 23, 2, 161-170.

Williams, H. and Wikstrom, F., 2011. Environmental impact of packaging and food losses in a life cycle perspective: a comparative analysis of five food items, J. of Clean. Prod., 12, 43-48.

Williams, H., Wilkstrom, F., Lofgren, M., 2008. A life cycle perspective on environmental effects of consumer focused packaging development, J. of Clean. Prod. 16, 7, 853-859.

Yin, R.K., 2012. Case Study Research: Design and Methods. 4. Sage, Thousand Oaks. 


\begin{tabular}{|c|}
\hline \\
\hline $\begin{array}{l}\text { Between fifteen and thirty percent of food is wasted by consumers and food institutions in Europe and } \\
\text { USA (see Quested and Johnson, 2009). }\end{array}$ \\
\hline $\begin{array}{l}\text { Less than } 3 \% \text { of food waste was recovered and recycled in } 2009 \text {, with the remainder going to landfills } \\
\text { or incinerators (EPA, 2011). }\end{array}$ \\
\hline $\begin{array}{l}\text { Food waste accounted for almost } 31 \text { million } \mathrm{mt} \text { (14\%) of the roughly } 220 \text { million } \mathrm{mt} \text { of municipal solid } \\
\text { waste in the United States in } 2008 \text { and cost roughly } \$ 1.3 \text { billion to landfill (Schwab, 2010). }\end{array}$ \\
\hline $\begin{array}{l}\text { Food waste represents significant amounts of money and other resources invested throughout food's } \\
\text { entire lifecycle to produce, store, transport, and otherwise handle something that does not ultimately } \\
\text { meet its intended purpose of feeding people (Buzby et al., 2011). }\end{array}$ \\
\hline $\begin{array}{l}\text { Under current projections, in order to feed the global population in } 2050 \text { ( } 9.3 \mathrm{bn} \text { est.), food production } \\
\text { must increase by } 70 \% \text {, and there is a significant need to reduce waste (see FAO, 2010) }\end{array}$ \\
\hline Key Impacts of Packaging Waste: \\
\hline $\begin{array}{l}\text { Packaging waste in the UK in } 2010 \text { was estimated at } 173.9 \mathrm{~kg} \text { per capita, and an average of } 163.8 \mathrm{~kg} \\
\text { across the EU-27 countries: recycling rates of } 60 \% \text { and } 63 \% \text {, respectively (see Da Cruz et al., 2014). }\end{array}$ \\
\hline $\begin{array}{l}\text { Approximately } 18.5 \text { million tons of plastics waste, or around } 39 \% \text { of demand, is accounted for by } \\
\text { packaging in Europe (Luijsterburg and Goossens, 2012). }\end{array}$ \\
\hline $\begin{array}{l}\text { Contribution of packaging material to the entire environmental impact of the food value chain estimated } \\
\text { at up to } 45 \% \text { : depending on product type and packaging material (Del Borghi et al., 2014). }\end{array}$ \\
\hline $\begin{array}{l}\text { Packaging waste is growing, accounting for between } 15 \% \text { and } 20 \% \text { of total municipal solid waste in } \\
\text { different countries (OECD, 2011). }\end{array}$ \\
\hline In the US, Australia and Canada, estimates suggest that packaging waste constitutes around $30-35 \%$ \\
\hline
\end{tabular}


Figure 1: The emphasis of prior studies within the agri-food supply chain

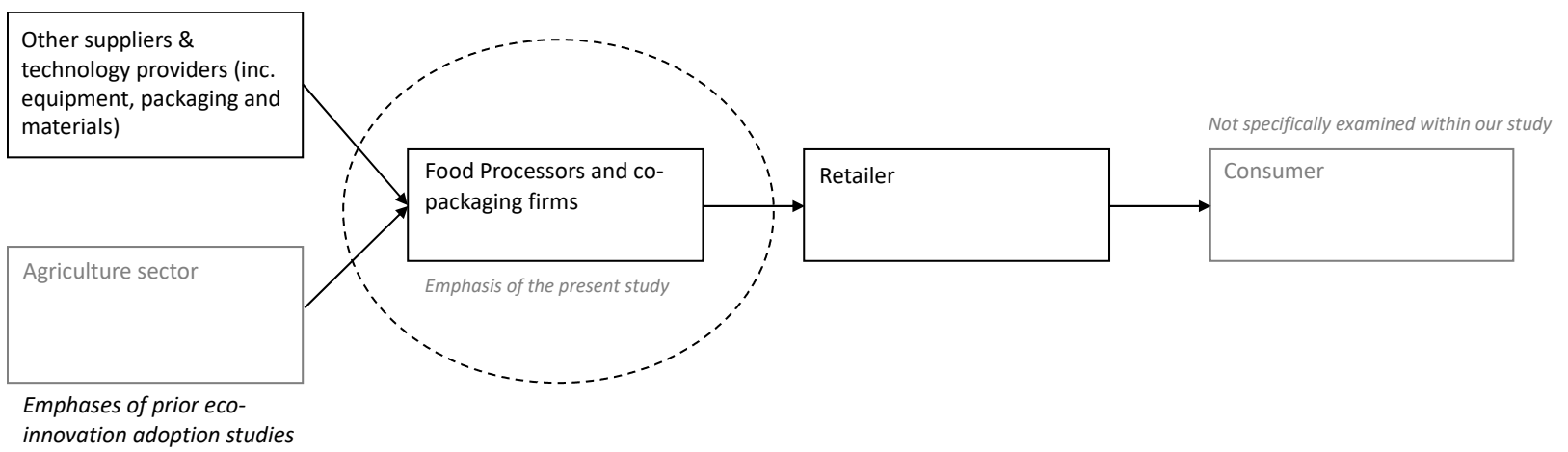


Table 2: Technological and organisational barriers pertinent to the adoption of ecoinnovations within the Food Supply Chain

\begin{tabular}{|c|c|c|c|}
\hline $\begin{array}{l}\text { Supply chain } \\
\text { position }\end{array}$ & $\begin{array}{l}\text { Category of } \\
\text { Barriers }\end{array}$ & $\begin{array}{l}\text { Barriers identified within: (i) technological eco-innovation \& } \\
\text { sustainability related studies \& (ii) broader innovation } \\
\text { studies (indicated in grey) }\end{array}$ & Sources \\
\hline \multirow{6}{*}{$\begin{array}{l}\text { Agricultural } \\
\text { Firm related } \\
\text { barriers }\end{array}$} & Organisational & $\begin{array}{ll}\text { - } & \text { Lack of management/business owner support } \\
\text { - } & \text { Reluctance to change established methods \& inertia }\end{array}$ & \multirow{6}{*}{$\begin{array}{l}\text { Long et al. (2016); } \\
\text { Mylan et al. (2015); } \\
\text { Cullen et al. (2013); } \\
\text { Eidt et al. (2012); } \\
\text { Lybbert and Summer } \\
\text { (2012); Bogdanski } \\
\text { (2011); Wheeler (2008). } \\
\text { Janssen and Swinnen } \\
\text { (2018). }\end{array}$} \\
\hline & Labor-related & $\begin{array}{l}\text { - Lack of required skills, capabilities and expertise } \\
\text { - Low technological awareness, understanding \& knowledge }\end{array}$ & \\
\hline & $\begin{array}{l}\text { Institutionall } \\
\text { supply chain }\end{array}$ & $\begin{array}{l}\text { - } \quad \text { Lack of fit between downstream supply chain partner } \\
\text { - } \quad \text { Strategy and operational reality } \\
\text { - } \quad \text { Short-term adversarial relationships with supermarkets } \\
\text { - } \quad \text { Regulatory \& policy issues impeding technology switching } \\
\text { - } \quad \text { Challenge in encompassing all links in the food chain } \\
\text { - } \quad \text { Lack of funding from other supply chain members }\end{array}$ & \\
\hline & Cost/economic & $\begin{array}{l}\text { - } \quad \text { Lack of identifiable economic benefit or insufficient ROI } \\
\text { - Costs, lack of access to capital \& limited resources for R\&D }\end{array}$ & \\
\hline & Information & $\begin{array}{l}\text { - Difficulties in measuring environmental impact/benefit } \\
\text { - Perceived lack of commercial benefit or consumer demand }\end{array}$ & \\
\hline & $\begin{array}{l}\text { Technology- } \\
\text { characteristics }\end{array}$ & - Fails to meet user needs or implementation overly complex & \\
\hline \multirow{6}{*}{$\begin{array}{l}\text { Technology } \\
\text { provider/ } \\
\text { supplier } \\
\text { related } \\
\text { barriers }\end{array}$} & Organisational & $\begin{array}{l}\text { - Lack of access to capital investment } \\
\text { - } \quad \text { Commoditisation of existing technologies hinders adoption }\end{array}$ & \multirow{6}{*}{$\begin{array}{l}\text { Long et al. (2016); Eidt } \\
\text { et al. (2012); Bogdanski } \\
\text { (2011); Wheeler (2008); } \\
\text { Del Rio Gonzalez } \\
\text { (2005); van Sluisveld } \\
\text { and Worrell (2013) } \\
\\
\text { Trott and Simms } \\
\text { (2017); Simms and } \\
\text { Trott (2014a,b). }\end{array}$} \\
\hline & Labor-related & - $\quad$ Buyers perceive a lack of credibility or authority of advisors & \\
\hline & $\begin{array}{l}\text { Institutional/ } \\
\text { supply chain }\end{array}$ & $\begin{array}{l}\text { - Lack of favorable policy landscape to facilitate adoption } \\
\text { - } \quad \text { wifficulties in gaining market involvement or relationships } \\
\end{array}$ & \\
\hline & Cost/economic & $\begin{array}{l}\text { - Challenge in proving value and demonstrating impact } \\
\text { - Too expensive/long ROI a challenge to investment }\end{array}$ & \\
\hline & Information & $\begin{array}{l}\text { - High-costs associated with early technology adoption \& } \\
\text { development }\end{array}$ & \\
\hline & $\begin{array}{l}\text { Technology } \\
\text { characteristics }\end{array}$ & $\begin{array}{l}\text { - } \quad \text { Perceived consumer lack of willingness to pay premium for } \\
\text { sustainable technologies } \\
\text { - } \quad \text { Concerns over conflicts with other functional requirements }\end{array}$ & \\
\hline \multirow[t]{7}{*}{$\begin{array}{l}\text { Food } \\
\text { processor/ } \\
\text { producer } \\
\text { related } \\
\text { barriers }\end{array}$} & Organisational & $\begin{array}{ll} & \text { Lack of senior management environmental leadership } \\
\text { - } & \text { Risk aversion \& the need for a high degree of risk tolerance } \\
\text { - } & \text { Existing technology perceived adequate to market needs } \\
\text { - } & \text { Innovation driven by the market \& customer demand } \\
\text { - } & \text { Low margins leading to emphasis on cost reduction }\end{array}$ & \multirow{7}{*}{$\begin{array}{l}\text { Santini et al., 2013; } \\
\text { Lowe et al. (2008); } \\
\text { Bossle et al. (2006); } \\
\text { Bhaskaran et al. } \\
\text { (2006). } \\
\text { Trott and Simms } \\
\text { (2017); Simms and } \\
\text { Trott (2014b); Caiazza } \\
\text { et al. (2014); } \\
\text { Avermaete et al. } \\
\text { (2004); Grunert et al., } \\
\text { (2005). }\end{array}$} \\
\hline & Labor-related & - Lack of innovation \& technical packaging capabilities or skills & \\
\hline & $\begin{array}{l}\text { Institutional/ } \\
\text { supply chain }\end{array}$ & $\begin{array}{l}\text { - } \quad \text { Insufficient government support } \\
\text { - } \quad \text { Lack of supply chain collaboration } \\
\text { - } \quad \text { Low industry product success rates, leading to incremental } \\
\quad \text { change \& risk averse decision-making }\end{array}$ & \\
\hline & Cost/economic & $\begin{array}{l}\text { - } \quad \text { Direct, indirect costs \& ROI } \\
\text { - } \quad \text { Challenge of addressing sustainability in a profitable strategy } \\
\text { - } \quad \text { High influence of process investments on decision-making }\end{array}$ & \\
\hline & Information & - Difficulty measuring sustainability level or technology impact & \\
\hline & $\begin{array}{l}\text { Technology } \\
\text { characteristics }\end{array}$ & $\begin{array}{l}\text { - Perceived lack of market potential for sustainable } \\
\text { technologies }\end{array}$ & \\
\hline & & $\begin{array}{l}\text { - } \quad \text { Impact on distribution costs } \\
\text { - } \quad \text { Risk of negative impact of technology on food quality } \\
\text { - } \quad \text { Potential negative impact of change on established brand }\end{array}$ & \\
\hline
\end{tabular}




\begin{tabular}{|c|c|c|c|}
\hline \multirow[t]{6}{*}{$\begin{array}{l}\text { Retailer } \\
\text { related } \\
\text { barriers }\end{array}$} & Organisational & $\begin{array}{l}\text { - } \quad \text { Lack of interest in eco-innovation in non-strategically } \\
\text { important \& less profitable categories } \\
\text { - } \quad \text { Lack of clear and consistent sustainability strategy } \\
\text { - } \quad \text { Category management emphasis: short-term, cost, \& growth } \\
\text { (commercial opportunity drives adoption) } \\
\text { - } \quad \text { Aversion to risk }\end{array}$ & \multirow{6}{*}{$\begin{array}{l}\text { Mylan et al. (2015); Hall } \\
\text { (2001); Chkanikova and } \\
\text { Mont (2015); Dijk } \\
\text { (2000); Smith (2007). } \\
\\
\text { Trott and Simms } \\
\text { (2017); Esberg et al. } \\
\text { (2016); Simms and } \\
\text { Trott (2014b); van } \\
\text { Everdingen et al. } \\
\text { (2011). }\end{array}$} \\
\hline & Labor-related & $\begin{array}{l}\text { - } \quad \text { Lack of environmental/sustainability capabilities \& expertise } \\
\text { - } \quad \text { Lack of internal innovation capabilities impede assessment }\end{array}$ & \\
\hline & $\begin{array}{l}\text { Institutionall } \\
\text { supply chain }\end{array}$ & $\begin{array}{l}\text { - Supply chain fragmentation \& poor communications } \\
\text { - } \quad \text { Inconsistent in guidance/policies from NGO's/government } \\
\text { - } \quad \text { Outsourced own-brand NPD; increases complexity in change }\end{array}$ & \\
\hline & Cost/economic & $\begin{array}{l}\text { - Emphasis on discounting strategies in certain categories } \\
\text { - } \quad \text { Costs \& reluctance to invest in sustainability } \\
\text { - } \quad \text { Emphasis on category growth } \\
\text { - Associated risks to own brand sales }\end{array}$ & \\
\hline & Information & - Difficulties in measuring and monitoring sustainability & \\
\hline & $\begin{array}{l}\text { Technology } \\
\text { characteristics }\end{array}$ & $\begin{array}{l}\text { - Potential decreases in quality } \\
\text { - } \quad \text { Perceived lack of commercial benefit due to insufficient } \\
\text { - Aversion to new technologies that may require changes in } \\
\text { product display and merchandising }\end{array}$ & \\
\hline \multirow[t]{3}{*}{$\begin{array}{l}\text { Consumer } \\
\text { related } \\
\text { barriers }\end{array}$} & Cost/economic & $\begin{array}{ll}\text { - } & \text { Intangibility of benefits \& perceived poor benefit-to-risk ratio } \\
\text { - } & \text { Confusion, aversion \& mistrust to new technologies } \\
\text { - } & \text { Financial constraints to purchasing higher price products } \\
\text { - } & \text { Assessment of cost versus benefit in new technologies }\end{array}$ & \multirow{3}{*}{$\begin{array}{l}\text { Steenis et al.'s (2017); } \\
\text { Wilkstrom et al. (2016); } \\
\text { Williams et al. (2008); } \\
\text { Bhaskaran et al., } \\
\text { (2006); Hanssen et al. } \\
\text { (2012) } \\
\text { van Everdingen et al. } \\
\text { (2011); Grunert et al. } \\
\text { (1997). }\end{array}$} \\
\hline & $\begin{array}{l}\text { Information/ } \\
\text { social }\end{array}$ & $\begin{array}{l}\text { - Unable to assess the environmental impacts of technologies } \\
\text { - } \quad \text { Lack of attention to implications of food waste in decision- } \\
\text { making } \\
\text { - } \quad \text { Consumer perceives benefits to primarily fall to industry } \\
\text { - } \quad \text { Lack of knowledge of technologies } \\
\text { - Conservative behavior \& aversion to food new products }\end{array}$ & \\
\hline & $\begin{array}{l}\text { Technology } \\
\text { characteristics }\end{array}$ & $\begin{array}{l}\text { - Concern over potential impact of technological and materials } \\
\text { changes on quality \& taste } \\
\text { - Averse to product changes negatively impacting on } \\
\text { convenience or use }\end{array}$ & \\
\hline
\end{tabular}


Figure 2: Conceptual Framework of Technology Adoption in the Food Processing Industry

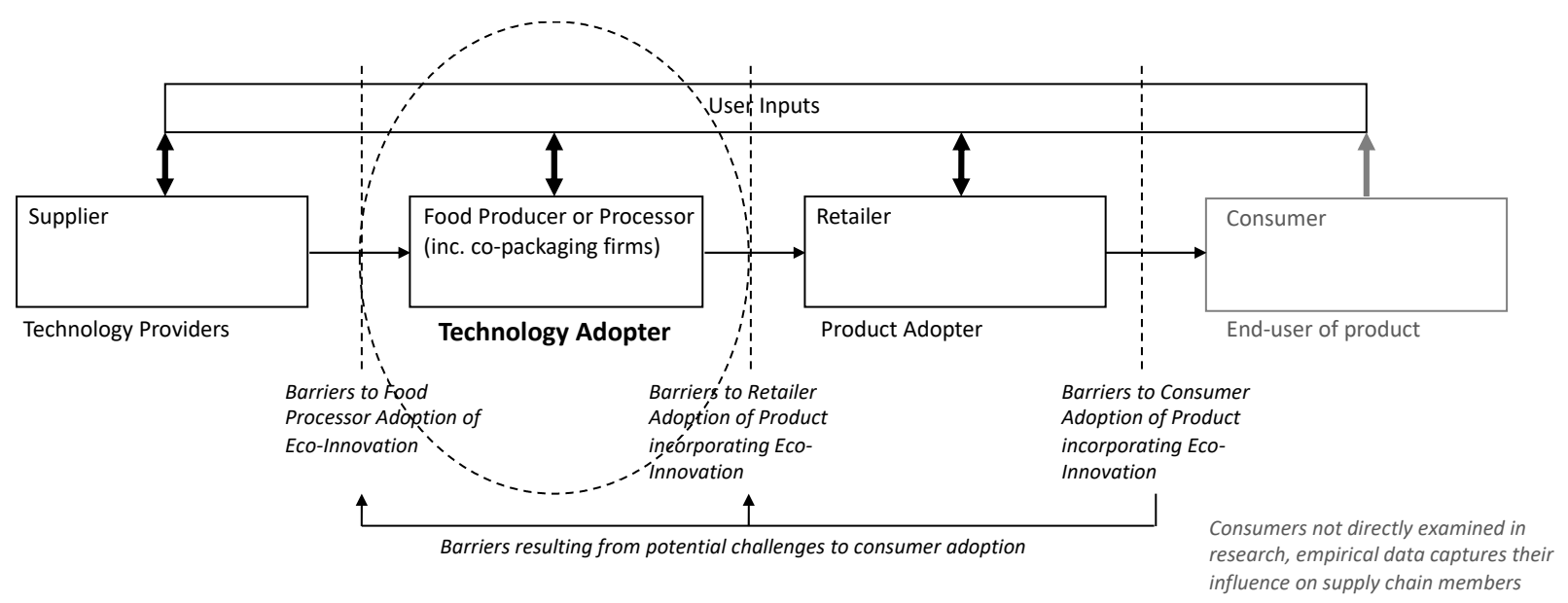


Table 3: Summary of Cases

\begin{tabular}{|c|c|c|c|c|}
\hline Cases & $\begin{array}{l}\text { Classification } \\
\text { of Innovation }\end{array}$ & $\begin{array}{l}\text { Relative } \\
\text { Adoption }\end{array}$ & $\begin{array}{l}\text { Potential Waste and Sustainability Benefits of } \\
\text { Technology }\end{array}$ & $\begin{array}{l}\text { Other Advantages and Disadvantages Associated with } \\
\text { Adoption }\end{array}$ \\
\hline $\begin{array}{l}\text { Case 1: Milk } \\
\text { bag with } \\
\text { Temperature } \\
\text { Responsive } \\
\text { Polymeric } \\
\text { Spine }\end{array}$ & $\begin{array}{l}\text { Packaging } \\
\text { format and } \\
\text { materials } \\
\text { innovation }\end{array}$ & Awaiting Trial & $\begin{array}{l}\text {-Reduction in weight } 85 \% \text { average compared to PET } \\
\text { and HDPE bottles, and cartons. } \\
\text {-In some cases existing bottles and cartons are either } \\
\text { not recyclable or simply not recycled by consumers. } \\
\text {-Ability to be compacted pre-filling, in transportation, and } \\
\text { in waste system. }\end{array}$ & $\begin{array}{l}\text {-Ability to easily fill within factory, compact size pre-filling. } \\
\text {-Rigidity when chilled. } \\
\text {-Initial unit cost increase of } 10 \% \text { compared to PET bottles, } \\
\text { but expected long-run savings. } \\
\text {-Need for new equipment investments. }\end{array}$ \\
\hline $\begin{array}{l}\text { Case } 2: \text { AMAP } \\
\text { for soft fruit and } \\
\text { vegetables } \\
\text { (whole and pre- } \\
\text { prepared/cut) }\end{array}$ & $\begin{array}{l}\text { Manufacturing } \\
\text { process } \\
\text { innovation }\end{array}$ & $\begin{array}{l}\text { Adopted by Six } \\
\text { Top EU } \\
\text { Retailers }\end{array}$ & $\begin{array}{l}\text { - Typical improvements in shelf life of } 1-4 \text { days } \\
\text { compared to laser pre-perforated films and } 1-10 \text { days } \\
\text { compared to current macro perforated packaging or } \\
\text { stretch film packaging. Resulting potential to doubling } \\
\text { shelf life for some produce. }\end{array}$ & $\begin{array}{l}\text {-No unit cost increases. } \\
\text {-Compatibility with existing packaging formats and materials } \\
\text {-Limited machinery investments. } \\
\text {-In-direct costs from associated changes in refrigeration } \\
\text { practices. }\end{array}$ \\
\hline $\begin{array}{l}\text { Case 3: } \\
\text { Biodegradable } \\
\text { lightweight } \\
\text { packaging for } \\
\text { raw meat }\end{array}$ & $\begin{array}{l}\text { Packaging } \\
\text { format and } \\
\text { materials } \\
\text { innovation }\end{array}$ & $\begin{array}{l}\text { Adopted by UK } \\
\text { Retailer for two } \\
\text { product lines, } \\
\text { currently in } \\
\text { market trial } \\
\text { phase. }\end{array}$ & $\begin{array}{l}\text {-Decreased packaging weight by a minimum of } 80 \% \text { in } \\
\text { comparison to a conventional meat tray. } \\
\text {-Increased shelf life of approximately } 5 \% \text {. } \\
\text {-Recyclable material. }\end{array}$ & $\begin{array}{l}\text {-Negative consumer perceptions resulting from some meat } \\
\text { 'browning', and feel of handling. } \\
\text {-Equipment investments required. } \\
\text {-Unit cost decreases of approximately } 20 \% \text {. }\end{array}$ \\
\hline $\begin{array}{l}\text { Case 4: } \\
\text { Lightweight } \\
\text { Material for } \\
\text { WRAP } \\
\text { sandwich } \\
\text { packaging }\end{array}$ & $\begin{array}{l}\text { Material } \\
\text { innovation }\end{array}$ & $\begin{array}{l}\text { Awaiting Trial: } \\
\text { Rejected by } \\
\text { one retailer }\end{array}$ & $\begin{array}{l}\text {-Material usage reduction up to } 80 \% \text { in comparison to } \\
\text { conventional packaging for wrap sandwiches. } \\
\text {-Biodegradable material. }\end{array}$ & $\begin{array}{l}-10 \% \text { reduction in production speed. } \\
\text {-Unit cost decreases of approximately } 40 \% \text { in comparison to } \\
\text { conventional packaging. }\end{array}$ \\
\hline
\end{tabular}


Figure 3: Research Framework- Design of Study

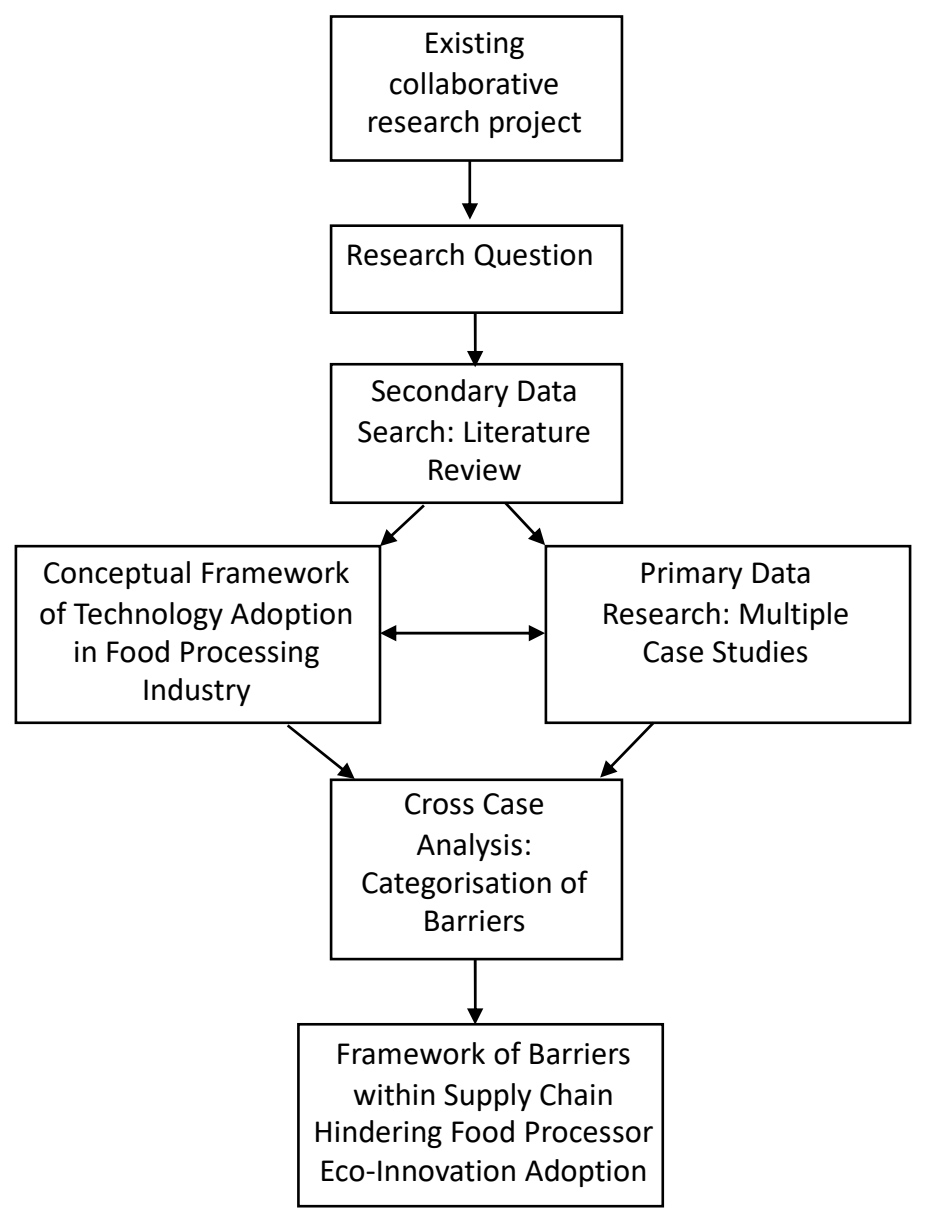


Figure 4: Barriers within the Supply Chain Hindering Food Processor's Adoption of Waste-Reducing Eco-Innovations

\begin{tabular}{|c|c|c|c|c|c|}
\hline & $\begin{array}{l}\text { Technology Provider- } \\
\text { Supplier Barriers }\end{array}$ & \multirow{11}{*}{$\begin{array}{l}\text { Technology } \\
\text { adoption }\end{array}$} & $\begin{array}{l}\text { Technology Adopter- } \\
\text { Food Producer/Processor Barriers }\end{array}$ & \multirow{11}{*}{$\begin{array}{l}\text { Product } \\
\text { adoption }\end{array}$} & $\begin{array}{l}\text { Product Adopter- } \\
\text { Retailer Barriers }\end{array}$ \\
\hline $\begin{array}{l}\text { A. Switching and } \\
\text { unit costs }\end{array}$ & $\begin{array}{l}\text { Costs too expensive for } \\
\text { customers. }\end{array}$ & & $\begin{array}{l}\text { Unit costs increases and production } \\
\text { investments (switching costs) associated } \\
\text { with adoption, combined with low margins. }\end{array}$ & & Barrier not applicable to retailer \\
\hline $\begin{array}{l}\text { B. Impact on } \\
\text { product } \\
\text { characteristics }^{2}\end{array}$ & $\begin{array}{l}\text { Barrier not applicable to } \\
\text { technology provider }\end{array}$ & & $\begin{array}{l}\text { Risk from change in consumer product use, } \\
\text { qualities or POS display. }\end{array}$ & & $\begin{array}{l}\text { Potential reduction in category performance } \\
\text { resulting from product change and impact on } \\
\text { retailing. }\end{array}$ \\
\hline $\begin{array}{l}\text { C. Retailing and } \\
\text { point of sale (POS) } \\
\text { risks }\end{array}$ & $\begin{array}{l}\text { Lack of understanding of retailers' } \\
\text { needs \& concerns. }\end{array}$ & & $\begin{array}{l}\text { Potential for changes to POS product } \\
\text { display or decisions to restock the product } \\
\text { (powerful retailer). }\end{array}$ & & $\begin{array}{l}\text { Concerns over potential negative impact of } \\
\text { changes to the product on existing POS } \\
\text { displays, product positioning and retailing. }\end{array}$ \\
\hline $\begin{array}{l}\text { D. Lack of } \\
\text { perceived market } \\
\text { opportunity }\end{array}$ & $\begin{array}{l}\text { Barrier not applicable to } \\
\text { technology provider }\end{array}$ & & $\begin{array}{l}\text { Perceived lack of consumer and retailer } \\
\text { demand or willingness to pay premium. }\end{array}$ & & $\begin{array}{l}\text { Lack of perceived potential to increase } \\
\text { category performance, due to limited consumer } \\
\text { demand and willingness to pay premium. }\end{array}$ \\
\hline $\begin{array}{l}\text { E. Simultaneous } \\
\text { processor-retailer } \\
\text { adoption }\end{array}$ & $\begin{array}{l}\text { Need for food processor and } \\
\text { retailer acceptance of technology. }\end{array}$ & & $\begin{array}{l}\text { Need for retailer technology/product } \\
\text { acceptance, and cooperation to conduct } \\
\text { shelf and distribution trials. }\end{array}$ & & $\begin{array}{l}\text { High-influence on technology acceptance in } \\
\text { food processors. }\end{array}$ \\
\hline $\begin{array}{l}\text { F. Poor } \\
\text { communications } \\
\text { and adversarial } \\
\text { relationships }\end{array}$ & $\begin{array}{l}\text { Commoditisation of existing } \\
\text { technologies, leads to poor } \\
\text { downstream supply chain } \\
\text { communications. }\end{array}$ & & $\begin{array}{l}\text { Short-term transition orientated, cost } \\
\text { focused, and adversarial relationships. }\end{array}$ & & $\begin{array}{l}\text { Adversarial relationships, lack of meaningful } \\
\text { communications, and price orientated } \\
\text { purchasing decisions. }\end{array}$ \\
\hline $\begin{array}{l}\text { G. High risk and } \\
\text { unproven } \\
\text { technologies }\end{array}$ & $\begin{array}{l}\text { Barrier not applicable to } \\
\text { technology provider }\end{array}$ & & $\begin{array}{l}\text { Need to ensure product safety, combined } \\
\text { with requirement of simultaneous adoption. }\end{array}$ & & $\begin{array}{l}\text { Lack of willingness to adopt technologies not } \\
\text { proven in use, and potential commercial risk. }\end{array}$ \\
\hline $\begin{array}{l}H . \text { Lack of equal } \\
\text { distribution of costs } \\
\text { and benefits }\end{array}$ & $\begin{array}{l}\text { Lack of ability to absorb costs, } \\
\text { due to low margins and long ROI. }\end{array}$ & & $\begin{array}{l}\text { Limited perceived benefits, combined with } \\
\text { retailer's lack of willingness to share unit or } \\
\text { investment costs. }\end{array}$ & & $\begin{array}{l}\text { Lack of willingness to jointly invest in new } \\
\text { equipment and price pressure on suppliers } \\
\text { (own brand and branded products). }\end{array}$ \\
\hline $\begin{array}{l}\text { I. Lack of required } \\
\text { capabilities }\end{array}$ & $\begin{array}{l}\text { Problems in demonstrating } \\
\text { environmental and non- } \\
\text { environmental benefits in practice. }\end{array}$ & & $\begin{array}{l}\text { Insufficient or lack of required production } \\
\text { and environmental capabilities. }\end{array}$ & & Barrier not applicable to retailer \\
\hline $\begin{array}{l}\text { J. Lack of } \\
\text { Consistent } \\
\text { Environmental } \\
\text { Guidance }\end{array}$ & $\begin{array}{l}\text { Barrier not applicable to } \\
\text { technology provider }\end{array}$ & & $\begin{array}{l}\text { Lack of consistency in guidance on } \\
\text { environmental priorities from retailers and } \\
\text { regulatory bodies. }\end{array}$ & & $\begin{array}{l}\text { Lack of consistent guidance from regulatory } \\
\text { bodies. }\end{array}$ \\
\hline
\end{tabular}

\footnotetext{
${ }^{2}$ Barrier not present in Case B, evident in all other cases.
} 


\section{Appendix: Detail of interviewees and interviews}

\begin{tabular}{|c|c|c|c|}
\hline Case & Company (interviewee) & Interview identifier and their Job Role & $\begin{array}{l}\text { No. of } \\
\text { Interviews }\end{array}$ \\
\hline \multirow{16}{*}{$\begin{array}{l}\text { Case 1: Milk bag } \\
\text { with } \\
\text { Temperature } \\
\text { Responsive } \\
\text { Polymeric Spine }\end{array}$} & Packaging manufacturer/technology provider & Technical services director & Two \\
\hline & Packaging manufacturer/technology provider & Head of R\&D & Twelve \\
\hline & Packaging manufacturer/technology provider & Sales manager: retailers & Three \\
\hline & Packaging manufacturer/technology provider & Sales manager: branded & Two \\
\hline & Packaging manufacturer/technology provider & Sales manager: FMCG client & Two \\
\hline & Packaging manufacturer/technology provider & Marketing Manager & One \\
\hline & Packaging manufacturer/technology provider & R\&D: Technical manager/engineer & One \\
\hline & Retailer & Technical packaging manager & Three \\
\hline & Multinational dev. manufacturer & Head of packaging design & Three \\
\hline & Global bev. manufacturer & Technical packaging manager & One \\
\hline & Industry body & Firm partner & Three \\
\hline & Local supplier to supermarket & Production manager & One \\
\hline & Brand owner of diary free milk alternatives & Long range planning manager & One \\
\hline & Top three retailer ${ }^{3}$ & Packaging buyer and reduction & One \\
\hline & Top three retailer ${ }^{3}$ & Packaging manager/technologist & Two \\
\hline & Food industry body & Head consultant & One \\
\hline \multirow{10}{*}{$\begin{array}{l}\text { Case 2: AMAP } \\
\text { for soft fruit and } \\
\text { vegetables } \\
\text { (whole and pre- } \\
\text { prepared) }\end{array}$} & AMAP technology provider & Managing Director & Five \\
\hline & AMAP technology provider & Technical Director & One \\
\hline & Technology partner & General Director & One \\
\hline & Food packaging and processing systems & Vice President rest of Europe & One \\
\hline & Food packaging and processing systems & Sales Agent & One \\
\hline & Food processor & Project Engineer & One \\
\hline & Fruits co-packer & Managing Director & Five \\
\hline & Fruits co-packer & Technical Director & One \\
\hline & Innovation agency & Project manager/sales agent & One \\
\hline & Sourcing company & Technical manager & One \\
\hline \multirow{6}{*}{$\begin{array}{l}\text { Case 3: } \\
\text { Biodegradable } \\
\text { lightweight } \\
\text { packaging for } \\
\text { raw meat }\end{array}$} & Packaging manufacturer/technology provider & Head of R\&D & Three \\
\hline & Packaging manufacturer/technology provider & Sales manager & Two \\
\hline & Packaging manufacturer/technology provider & Head of production & Two \\
\hline & Packaging manufacturer/technology provider & Marketing manager & Two \\
\hline & Top four retailer ${ }^{3}$ & Head of Packaging & Four \\
\hline & Top four retailer ${ }^{3}$ & Packaging Manager & One \\
\hline
\end{tabular}

\footnotetext{
${ }^{3}$ In terms of market share
} 


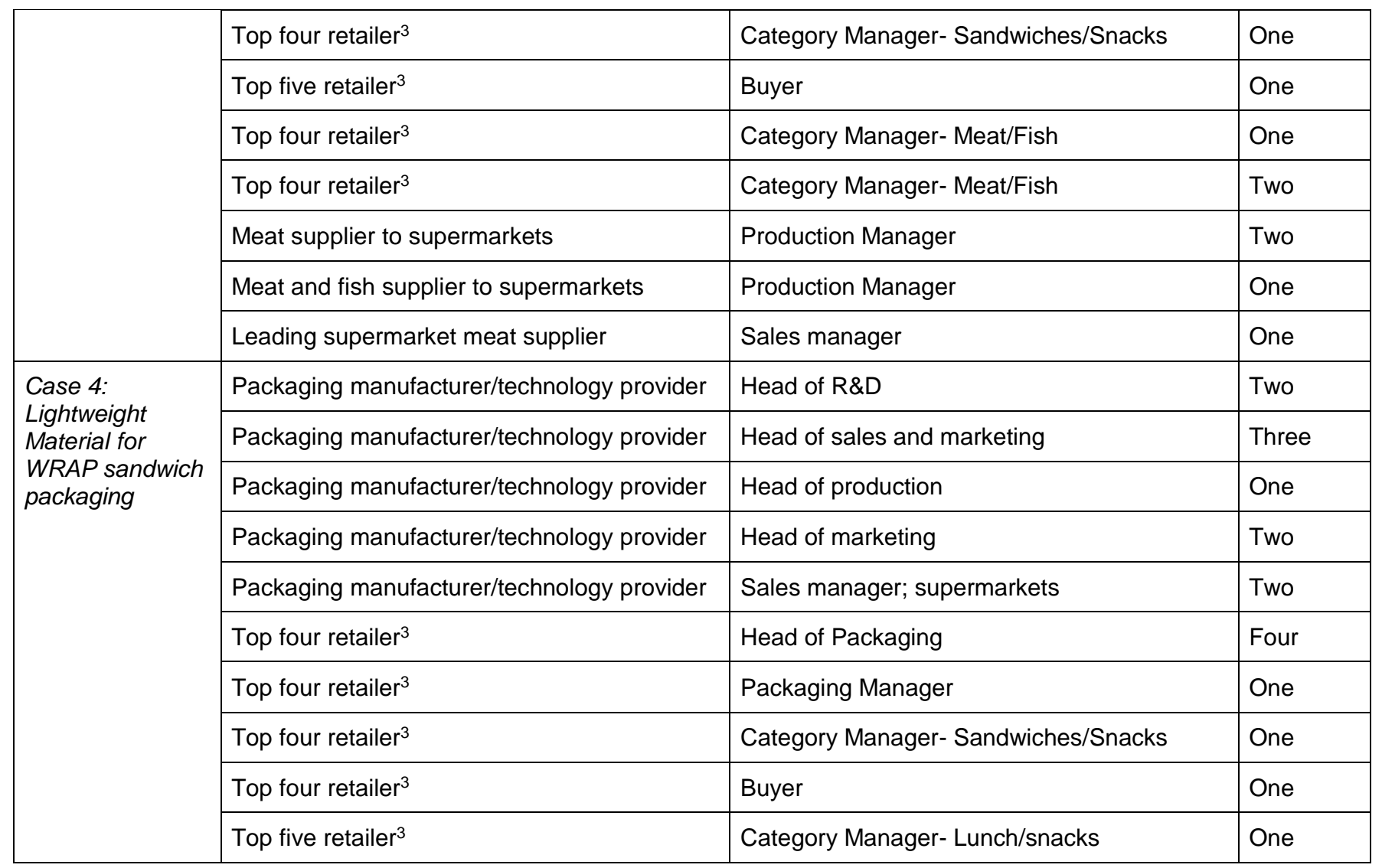

